\title{
Employing a composite gene-flow index to numerically quantify a crop's potential for gene flow: an Irish perspective
}

\author{
Marie-Louise FLANNERY ${ }^{1}$, Conor MEADE ${ }^{2}$ and Ewen MULLINS ${ }^{1 *}$ \\ 1 Teagasc Crops Research Centre, Oakpark, Carlow, Co. Carlow, Ireland \\ ${ }^{2}$ Gene-flow Laboratory, Institute of Bioengineering and Agroecology, National University of Ireland Maynooth, Co. Kildare, Ireland
}

\begin{abstract}
Guidelines to ensure the efficient coexistence of genetically modified (GM) and conventional crops are currently being considered across the European Union. The purpose of this strategy is to describe the measures a farmer must adopt to minimize the admixture of GM and non-GM crops. Minimizing pollen / seed-mediated gene flow between GM and non-GM crops is central to successful coexistence. However no system is currently available to permit the numeric quantification of a crop's propensity for pollen/seed-mediated gene flow. The provision of such a system could permit a background level of gene flow, specific for a particular conventional crop, to be calculated. Here we present a gene flow index model implemented using the principal arable crops in Ireland as a model dataset. The objective of this research was to establish a baseline gene flow data set for Ireland's primary conventional crops through the provision of a simple numerical index. This Gene Flow Index (GFI) incorporates four strands of crop-mediated gene flow (crop pollen-to-crop, crop pollen-to-wild, crop seed-tovolunteer and crop seed-to-feral) into a format that permits the calculation of a crop's gene flow potential. Responsive to regional parameters, we have applied the model to sugar beet, oilseed rape, potato, ryegrass, maize, wheat and barley. We propose that the attained indices will highlight those crops that require additional measures in order to minimize gene flow in accordance with anticipated coexistence guidelines.
\end{abstract}

Keywords: gene flow / GM / genetically modified / Ireland / risk assessment / gene flow index / coexistence / transgenic

Abbreviations: GM: Genetically modified; ERA: environmental risk assessment; GFI: gene flow index

\section{INTRODUCTION}

For successful pollen-mediated gene flow, pollen has to find and fertilize a compatible recipient plant (i.e. an interfertile wild relative or crop), which in turn must result in the formation of a fertile hybrid. Although hybrids may develop spontaneously, it is not automatically implied that they will be able to establish, survive and reproduce in the wild (Hauser et al., 2003a, b). The same is true for seed-mediated gene flow: it is only a reality if the germinating seed gives rise to a viable reproductive adult population.

In Europe, the issue of gene flow is of particular significance when the coexistence of GM and non-GM crops is considered. Present guidelines on coexistence direct that gene flow from a GM crop must be sufficiently restrictive to minimize the potential admixture of GM material with conventional/organic crops (European Commission, 2003). For seed-mediated gene flow, one way this can be achieved is through the implementation of a stringent management system (Tolstrup et al., 2003). For pollen-mediated gene flow the issue is more complex as the frequency of transgene flow is influenced by multiple factors (i.e., pollen viability, size of pollen sources, the availability of a flowering recipient population, local topography). To offset this potential avenue for gene flow, isolation distances between the GM and non-GM crop have been recommended as one of several measures to ensure the effective coexistence of GM and conventional/organic crops (Advisory Committee on Releases to the Environment, 2004; Tolstrup et al., 2003). However, while isolation distances are appropriate

\footnotetext{
* Corresponding author: emullins@ oakpark.teagasc.ie
} 
Table 1. Agricultural and production acreage of the principal crops cultivated in Ireland with their associated wild relatives (Raybould and Gray, 1993; Meade and Mullins, 2004).

\begin{tabular}{|c|c|c|c|c|c|}
\hline Crop & $\begin{array}{c}\% \text { Total } \\
\text { agricultural } \\
\text { acreage }\end{array}$ & $\begin{array}{l}\% \text { of arable } \\
\text { acreage }\end{array}$ & $\begin{array}{c}\text { Native/ } \\
\text { Naturalised } 1\end{array}$ & Wild relative $^{2}$ & $\begin{array}{l}\text { Hybrids } \\
\text { recorded } \\
\text { in Ireland }^{3}\end{array}$ \\
\hline $\begin{array}{l}\text { Ryegrass } \\
\text { (Lolium perenne) }\end{array}$ & 80 & - & $\mathrm{Y}$ & $\begin{array}{l}\text { Meadow fescue (Festuca pratensis) } \\
\text { Semi-wild Italian ryegrass (Lolium multiflorum) } \\
\text { Semi-wild perennial ryegrass (Lolium perenne) }\end{array}$ & $\begin{array}{l}\mathrm{Y} \\
\mathrm{Y} \\
\mathrm{Y}\end{array}$ \\
\hline $\begin{array}{l}\text { Barley } \\
\text { (Hordeum vulgare) }\end{array}$ & 4 & 46 & $\mathrm{~N}$ & $\begin{array}{l}\text { Wall barley (Hordeum murinum) } \\
\text { Meadow barley (H. secalinum) }\end{array}$ & $\begin{array}{l}\mathrm{N} \\
\mathrm{N}\end{array}$ \\
\hline $\begin{array}{l}\text { Wheat } \\
\text { (Triticum aestivum) }\end{array}$ & 2 & 24 & $\mathrm{~N}$ & --- & --- \\
\hline $\begin{array}{l}\text { Sugar beet (Beta } \\
\text { vulgaris spp. vulgaris) }\end{array}$ & 0.7 & 8 & $\mathrm{Y}$ & $\begin{array}{l}\text { Sea beet (Beta vulgaris ssp. maritima) } \\
\text { Weed beet }(B . \text { vulgaris } \mathrm{spp} \text {. vulgaris })\end{array}$ & $\begin{array}{l}? \\
\mathrm{Y}\end{array}$ \\
\hline Maize (Zea mays) & 0.45 & 3.5 & $\mathrm{~N}$ & --- & --- \\
\hline $\begin{array}{l}\text { Potato } \\
\text { (Solanum tuberosum) }\end{array}$ & 0.36 & 3.6 & $\mathrm{~N}$ & $\begin{array}{l}\text { Woody nightshade (Solanum dulcamara) } \\
\text { Black nightshade (Solanum nigrum) }\end{array}$ & $\begin{array}{l}\mathrm{N} \\
\mathrm{N}\end{array}$ \\
\hline $\begin{array}{l}\text { Oilseed rape (Brassica } \\
\text { napus) }\end{array}$ & 0.04 & 0.06 & Y & $\begin{array}{l}\text { Wild mustard (B. nigra) } \\
\text { Wild cabbage (B. oleracea) } \\
\text { Wild turnip }(\text { B. rapa) } \\
\text { Brown mustard (B. juncea) } \\
\text { Wild radish (Raphanus raphanistrum) } \\
\text { White mustard (Sinapis alba) } \\
\text { Charlock (S. arvensis) } \\
\text { Hoary mustard (Hirschfeldia incana) }\end{array}$ & $\begin{array}{l}? \\
? \\
? \\
? \\
? \\
? \\
? \\
? \\
?\end{array}$ \\
\hline
\end{tabular}

\footnotetext{
${ }^{1} \mathrm{Y}=$ yes, $\mathrm{N}=$ no (source: Webb et al., 1996).

2 Interfertile with crop and/or of same genus as crop.

${ }^{3} \mathrm{Y}=$ yes, ? = not known in Ireland but recorded elsewhere, $\mathrm{N}=$ not recorded in Ireland or elsewhere (source: Raybould and Gray, 1993; Stace, 1984; Webb et al., 1996).
}

for minimizing crop-to-crop gene flow, this mechanism will not necessarily restrict pollen-mediated gene flow from a GM/non-GM crop to a related wild species. Of most relevance to this is clearly the presence/absence of inter-fertile wild relatives within/adjacent to the crop in question.

In Ireland, farmers cultivate a variety of crops (Tab. 1) that may or may not have wild relatives growing on the island (Meade and Mullins, 2005; Preston et al., 2002; Webb et al., 1996). In general, the depauperate nature of the Irish flora presents a more limited array of crop wild relatives than is the case elsewhere in Europe. So, whereas wheat, barley, potatoes, and maize are introduced species without inter-fertile wild relatives; ryegrass, oilseed rape and sugar beet have native or naturalized wild relatives, raising the possibility that commercial GM varieties of these latter crops will interbreed with other varieties already growing in Ireland (Meade and Mullins, 2005).

A traditional commentary associated with such a gene flow event would gauge the risk of transgene transfer into the wild population as being high, medium or low. This system has been employed by several authors and when accompanied with a detailed description can be informative enough to assist the reader in understanding the issues (Eastham and Sweet, 2002). The Department of the Environment, Food and Rural Affairs (DEFRA) in the United Kingdom(UK) have employed an extension of this system and categorized the likelihood of harmful effects occurring as high, medium, low or negligible, with the magnitude of the harmful effects being severe, moderate, low or negligible (DEFRA, 2001). They have acknowledged though that further refinement of this classification system is required as "the behavior of any organism in the environment is influenced by many interacting factors, and we are not yet in a position to take a quantitative approach with any confidence" (DEFRA, 2001).

This invites the question of whether it is possible to numerically quantify the level of gene flow from a GM crop? The substitution of a "high, medium, low" classification with a sensitive numerical index could have benefits for both the consumer and the research scientist. For the former, the provision of a distinguishable scale would 
assist them in understanding the risk/benefit of a particular GM crop. For the scientist, it could introduce a level of diagnostic uniformity across independent research studies. Data normalized in this way could:

(i) provide a reliable criterion for pre-selecting GM crops based on their suitability to local agroecological conditions, even prior to GM crop research and development;

(ii) permit a more dependable comparison to be made between studies from disparate regions.

Previous gene flow indices or botanical files have been proposed as a tool to assist risk assessment strategies. In 1992, de Vries et al. presented a study of the likelihood of crop-to-wild relative gene flow in the Netherlands. They further expanded the concept in 1996 by addressing the logistics of a European Botanical File (Frietema De Vries, 1996), whilst in 2001 Ammann et al. discussed the potential of the same system to monitor gene flow in Switzerland. More recently, as part of the Bulgarian Biosafety Framework, an UNEP-GEF funded project (Programme, 2003) has set about preparing botanical files for over 61 plant species based on the earlier model of de Vries (de Vries et al., 1992).

De Vries et al. (1992) analyzed the potential for spontaneous gene flow by examining three codes of dispersal: dispersal of pollen $\left(\mathrm{D}_{\mathrm{p}}\right)$, dispersal of diaspores $\left(\mathrm{D}_{\mathrm{d}}\right.$ : fruit and seed) and the frequency of wild relatives $\left(D_{f}\right)$. Though the index does not address the potential impact of a transgene on a related crop/wild relative (Conner et al., 2003), Ammann et al. (2001) have highlighted the necessity for a fourth code that would attend to this issue.

A stated objective by the authors of the latter paper was to stimulate debate on the suitability of gene flow indices as a mechanism to gauge the risk associated with GM crop cultivation (Ammann et al., 2001). Yet, prior to determining the consequences of a gene flow event from a specific GM crop variety, the potential for that gene flow event to occur must first be determined. Preceding this, a background level of gene flow from an equivalent conventional crop must be recorded. In this paper we propose expanding the gene flow index (GFI) system to specifically include seed-mediated gene flow, the role of feral crop populations and pollen-mediated crop-to-crop gene flow. To achieve this we present a numerical scale that combines four strands of analysis, which when pooled, generate a novel composite assessment of the potential for gene flow from each of the listed conventional crops. While, the consequences of a gene flow event will vary tremendously between GM crops and even amongst GM varieties; the provision of a system that permits the quantification of a crop's potential for gene flow could facilitate the implementation of a national coexistence strategy.

\section{MODEL DESCRIPTION}

In designing the crop Gene Flow Index (GFI) model presented in this paper, we capitalized on information resources currently available in the public domain. The findings presented here are based on data collected from a broad literature base (scientific journals and reports), considered in conjunction with field data from Teagasc Oak Park and information from the Teagasc Farm Advisory Service. Notably, only information that pertains to systems comparable to the Irish agricultural and geographical environment was utilized.

The GFI model evaluates baseline data for the main crops grown in Ireland and includes such minority crops as oilseed rape and maize. In clarifying the parameters of the model, the calculated GFI value pertains to the propensity of each crop to form viable hybrid/volunteer/ feral individuals. For the purposes of this study we have made a clear distinction between the volunteer and feral niches based on the ability of a plant to grow within/ outside a managed crop system respectively (Devos et al., 2004). These and additional terms/abbreviations are defined in Table 2.

In completing this analysis, our specific intention was to focus solely on the potential for gene flow from a cultivated crop species (e.g. crop to related wild relative); as such, alternative pathways for gene flow (e.g. wild, volunteer or feral originating pollen to a related crop) were not considered but have been discussed later (see Sect. Model discussion and Figs. 1B and 1C). The model (Tab. 3) retains a simple format and is composed of four strands representing the four principle modes of pollen/ seed-mediated gene flow (Fig. 1A): crop pollen-to-wild relative (CPW); crop pollen-to-crop (CPC); crop seed-tovolunteer (CSV) and crop seed-to-feral (CSF). Each strand contains several sequential questions with each question designed to provide a "yes/no" answer, which in turn equates to a relevant score. By following this linked progression, when a question incurs an answer with a zero value that strand automatically records a total value of zero, as no gene flow can take place for the specified crop under the selected criterion. The adoption of this worstcase scenario approach is intentional and complements a previous discussion (Wilkinson et al., 2003), which advocates the use of a more structured system to assess any potential risk. As such, it maintains the practicality of the model by encompassing real-life factors that while not 
Table 2. Abbreviations, terms and definitions employed during GFI analysis.

\begin{tabular}{l|l}
\hline $\begin{array}{l}\text { Gene flow } \\
\text { Successful gene flow } \\
\text { Viable }\end{array}$ & $\begin{array}{l}\text { Transfer of genetic material from a donor plant through the dispersal of pollen or seed } \\
\text { A gene flow event that results in the formation of a viable hybrid } \\
\text { Relates to the ability of a hybrid to survive and reproduce }\end{array}$ \\
Hybrid & $\begin{array}{l}\text { Plant that has arisen due to a successful gene flow event } \\
\text { Gene Flow Index - a numerical index designed to quantify a crop's propensity for gene flow } \\
\text { CPC }\end{array}$ \\
SPW & $\begin{array}{l}\text { Strand to quantify a successful crop pollen-mediated gene flow event to a related crop } \\
\text { Strand to quantify a successful crop seed-mediated gene flow event which results in the establishment } \\
\text { of a feral individual } \\
\text { CSFand to quantify a successful crop seed-mediated gene flow event which results in the establishment } \\
\text { of a volunteer individual } \\
\text { A plant that has arisen from a seed-mediated gene flow event from a crop and is growing within the } \\
\text { confines of a managed agricultural system } \\
\text { A reproducible plant that has arisen from a seed-mediated gene flow event from a crop and is growing } \\
\text { outside the confines of a managed agricultural system (e.g. hedgerow, roadside) } \\
\text { A wild or weedy species/variety that is genetically related to and interfertile with a commercially } \\
\text { cultivated crop }\end{array}$ \\
Feral* & Wild relative
\end{tabular}

* Definition of volunteer and feral adapted from Devos et al. (2004).

desired, will occur all the same; for example the occurrence of bolters in a sugar beet crop. Note, for the purposes of this paper the characterization of "seeddispersal" relates to the dispersal of either/both the produced seed and tuber of the described crop.

\section{Strand CPW (Crop pollen-to-wild relative gene flow)}

Five questions are presented to forecast the propensity for successful pollen-mediated gene flow between the crop and a related wild species.

CPW1: Do inter-fertile wild relatives of this crop exist in Ireland?

The presence of wild relatives in the vicinity of the crop increases the likelihood of hybridization between them. However, for hybridization to occur relatives must be compatible with the crop species: taxa belonging to the same genus or taxonomic group as a given crop but which are not inter-fertile with it do not contribute to the score (even if they are recorded as wild relatives in the broad sense - see Tab. 1).

CPW2: Is there a probability that the crop will flower and produce viable pollen during its cultivation?

For such crops as barley, oilseed rape and wheat, flowering is an essential process as the marketable product of the crop is the resulting seed. In other crop systems (e.g. sugar beet) flowering and cross-pollination are undesirable as their occurrence can impede the accumulation of reserves within the harvested product. However, bolters do occur within beet crops and as such provide a mechanism for gene flow. Equally it is not possible in many swards of ryegrass to prevent a minority of individual plants from flowering before harvest.

CPW3: Upon flowering, is $95 \%$ of the crop pollen deposited within $1 \mathrm{~m}$ (1), $10 \mathrm{~m}$ (2), $50 \mathrm{~m}$ (3), $100 \mathrm{~m}$ (4), $250 \mathrm{~m}$ (5) or $500 \mathrm{~m}(6)$ ?

The further pollen travels the higher the probability that a receptive wild relative will be encountered. Yet, the typical leptokurtic dispersal pattern of pollen ensures that it is practically impossible to attain the distance up to which $100 \%$ of deposited pollen is contained within, especially when insect-mediated transfer is considered. To rectify this, we have adopted a $95 \%$ confidence interval and assumed that $95 \%$ of the time, $95 \%$ of the pollen will travel a specific distance. This assumption simplifies the interpretation of research that has been completed over the last few years into pollen dispersal and we believe negates the necessity to separate wind- and insect-mediated pollen flow.

CPW4: If flowering does occur is the wild relative in question rated as an obligate inbreeder (0), a partial inbreeder/outbreeder (1) or an obligate outbreeder (2)?

The potential for successful gene flow is greatly affected by the degree of outcrossing, which is typical of pollen recipients, be they crop plants, volunteers, weeds or wild relatives. Therefore while the ability of the donor crop to produce viable pollen (CPW3) is critical to initiate 


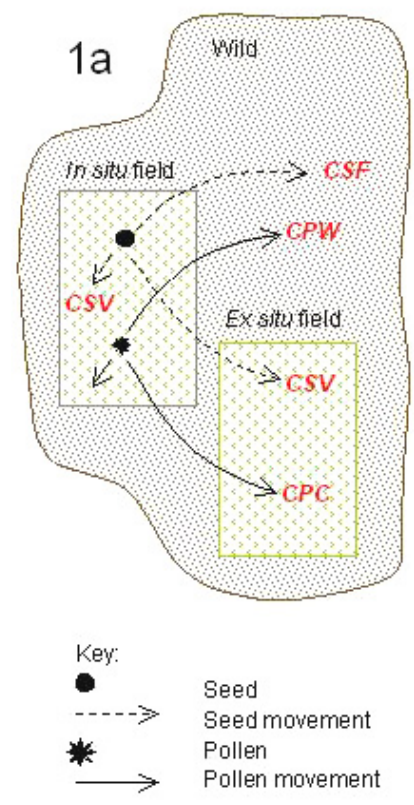

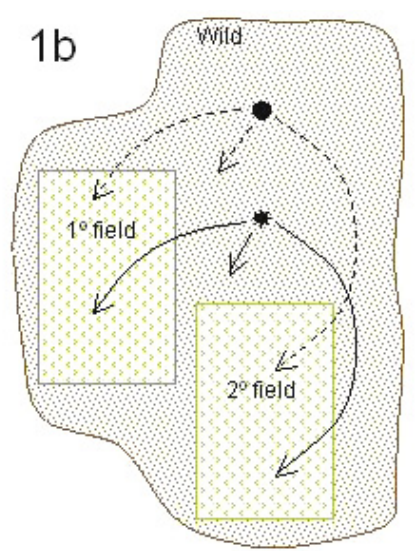

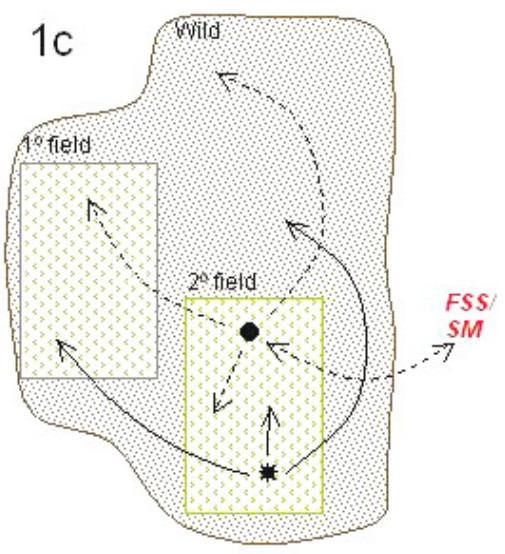

Figure 1. Potential avenues for gene-flow from a managed crop to the in situ field habitat, the ex situ field habitat and the wild habitat. Solid and dashed lines represent pollen and seed movement respectively. 1A: The four gene-flow strands included in the composite GFI model. CSF - crop seed to feral. CPW - crop pollen to wild. CPC - crop pollen to other crop. CSV - crop seed to volunteer. 1B: Potential outcomes of strands CSF and CPW with gene flow into primary $\left(1^{\circ}\right)$ and/or secondary $\left(2^{\circ}\right)$ fields. 1C: Potential outcome of strands CPC and CSV where viable hybrids could contribute to gene flow into the same $\left(2^{\circ}\right)$ or adjacent fields $\left(1^{\circ}\right)$ or could inadvertently be incorporated into seed collected for farm saved seed (FSS) or seed multiplication (SM) purposes. See text for discussion. gene flow; the ability of the pollen receptor to receive external pollen is equally important. The inclusion of this question ensures continuity between analyzing the potential of the donor to provide pollen relative to the ability of the receptor plant to receive pollen.

CPW5: If fertilization is achieved by the deposited pollen, will a viable $F_{1}$ hybrid individual establish itself?

This question is relevant in gene flow terms as the ecological and genetic consequences depend on the extent and direction of gene flow, in addition to the viability of the hybrids (Bartsch et al., 2001). So while crop-wild hybrids will normally persist in the local environment, environmental factors such as frost or increased/ decreased competition from natural competitors and pests could prevent the hybrid from establishing a niche for itself.

\section{Strand CPC (Crop pollen-to-crop gene flow)}

The principle aim of coexistence is to minimize pollen admixture and the subsequent mixing of hybridized seed (containing the transgene) within a non-GM seed lot, which could present labeling and crop management problems. The potential of pollen-mediated crop-to-crop gene flow is therefore relevant in the context of coexistence, where isolation distances (Tolstrup et al., 2003) have been adopted as a measure to assist in the segregation of GM and related non-GM crops. Hence, to address a crop's potential for pollen-mediated crop-tocrop gene flow, a modification of the strand described for crop-to-wild (Strand CPW) is required. As an equivalent to CPW1 is redundant for this strand, this 4-question analysis progresses with the questions:

CPC1: Is there a probability that the crop will flower and produce viable pollen during its cultivation?

CPC2: Upon flowering, is $95 \%$ of the crop pollen deposited within $1 \mathrm{~m}$ (1), $10 \mathrm{~m}$ (2), $50 \mathrm{~m}$ (3), $100 \mathrm{~m}$ (4), $250 m(5)$ or $500 m(6)$ ?

The distance crop pollen travels is key to maintaining an effective isolation distance, thereby ensuring that the adventitious presence of GM material in non-GM produce does not exceed the established thresholds. 
Table 3. Components of proposed Gene Flow Index (GFI) describing the propensity for successful pollen and/or seed-mediated gene flow through four possible strands: strand CPW for crop pollen-to-wild gene flow, strand CPC for crop pollen-to-crop, strand CSV for crop seed-to-volunteer and strand CSF for crop seed-to-feral.

\begin{tabular}{|c|c|c|}
\hline Strand & Question & Score \\
\hline CPW & Propensity for successful pollen-mediated gene flow between the crop and wild relatives & \\
\hline CPW1 & Do interfertile wild relatives of this crop exist in Ireland? & $0 / 1$ \\
\hline CPW2 & Is there a probability that the crop will flower and produce viable pollen during its cultivation? & $0 / 1$ \\
\hline CPW3 & $\begin{array}{l}\text { Upon flowering, is } 95 \% \text { of the crop pollen deposited within } \\
1 \mathrm{~m}(1), 10 \mathrm{~m}(2), 50 \mathrm{~m}(3), 100 \mathrm{~m}(4), 250 \mathrm{~m}(5) \text { or } 500 \mathrm{~m}(6) ?\end{array}$ & $1 / 2 / 3 / 4 / 5 / 6$ \\
\hline CPW4 & $\begin{array}{l}\text { If flowering does occur is the wild relative in question rated as an obligate inbreeder (0), a partial } \\
\text { inbreeder/outbreeder (1) or an obligate outbreeder (2)? }\end{array}$ & $0 / 1 / 2$ \\
\hline CPW5 & If fertilization is achieved by the deposited pollen, will a viable $\mathrm{F}_{1}$ hybrid individual establish itself? & $0 / 1$ \\
\hline Strand & Question & Score \\
\hline CPC & $\begin{array}{l}\text { Propensity for successful pollen-mediated gene flow between the crop and related commercial } \\
\text { varieties }\end{array}$ & \\
\hline CPC1 & Is there a probability that the crop will flower and produce viable pollen during its cultivation? & $0 / 1$ \\
\hline $\mathrm{CPC} 2$ & $\begin{array}{l}\text { Upon flowering, is } 95 \% \text { of the crop pollen deposited within } \\
1 \mathrm{~m}(1), 10 \mathrm{~m}(2), 50 \mathrm{~m}(3), 100 \mathrm{~m}(4), 250 \mathrm{~m} \text { (5) or } 500 \mathrm{~m}(6) ?\end{array}$ & $1 / 2 / 3 / 4 / 5 / 6$ \\
\hline $\mathrm{CPC} 3$ & $\begin{array}{l}\text { If flowering does occur is the receptive crop rated as an obligate inbreeder (0), a partial inbreeder/ } \\
\text { outbreeder (1) or an obligate outbreeder (2)? }\end{array}$ & $0 / 1 / 2$ \\
\hline CPC4 & $\begin{array}{l}\text { If fertilization is achieved by the deposited pollen, will a viable } \mathrm{F}_{1} \text { individual establish itself from the } \\
\text { hybrid seed in the absence of mechanical/chemical control? }\end{array}$ & $0 / 1$ \\
\hline Strand & Question & Score \\
\hline CSV & Propensity for successful seed-mediated* gene flow from commercial crop to volunteer & \\
\hline CSV1 & Does the crop produce seed during its cultivation? & $0 / 1$ \\
\hline CSV2 & Post-harvest, will the seed survive and germinate within the confines of a managed field? & $0 / 1$ \\
\hline CSV3 & Will the volunteer develop into a viable individual? & $0 / 1$ \\
\hline Strand & Question & Score \\
\hline CSF & Propensity for successful seed-mediated* gene flow from commercial crop to feral & \\
\hline CSF1 & Does the crop produce seed during its cultivation? & $0 / 1$ \\
\hline CSF2 & Following transfer from the site of cultivation will wayward seed survive and germinate? & $0 / 1$ \\
\hline CSF3 & Will the resulting individuals establish into a viable feral population? & $0 / 1$ \\
\hline
\end{tabular}

* "Seed-mediated" encompasses both flower originating seed and root derived tubers.

CPC3: If flowering does occur is the receptive crop rated as an obligate inbreeder ( 0$)$, a partial inbreeder/ outbreeder (1) or an obligate outbreeder (2)?

Analogous to CPW4, the occurrence of a successful pollen-mediated gene flow event is reliant upon the ability of the receptor plant to receive pollen. Factoring in floral architecture and the synchronicity of flowering, the degree of receptivity is variable amongst crops and between varieties within a crop (e.g. potato).

CPC4: If fertilization is achieved by the deposited pollen, will $a$ viable $F_{1}$ individual establish itself in the absence of mechanical/chemical control?
As strand CPC is restricted to within the confines of a managed crop system, it should be assumed that mechani$\mathrm{cal} /$ chemical control measures would be employed between rotations. Subsequently, it can then be accepted that the majority of crop pollen-to-crop hybrids would not survive. However, scenarios exist where the establishment of an $\mathrm{F}_{1}$ population could occur. For example, where the land is let go fallow during the rotation or where the seed from the receptor crop is harvested and saved on site for future cultivation ("farm saved seed") rather than being sold on to the merchant. In the case of farm saved seed, the cultivation of pollen-derived crop-to-crop $\mathrm{F}_{1}$ individuals is likely to 
occur without the knowledge of the grower. If this is the case and the donor pollen originated from a GM crop, it is likely to complicate the crop management regime of the farmer.

\section{Strand CSV (Crop seed-to-volunteer gene flow)}

Following on from the previous strand, which addressed pollen-mediated crop-to-crop gene flow, is the potential of a crop-derived seed to develop into a volunteer. Seed spillage is an unwanted but assured outcome of harvesting. Testament to this is the issue of managing volunteer populations within a rotation (e.g. recurrence of oilseed rape volunteers from long-lived seed banks), which can provide a conduit for seed-mediated gene flow. In this model, three questions serve to address a crop's potential for successful seed-mediated gene flow within the confines of an agricultural system:

CSV1: Does the crop produce seed during its cultivation?

CSV2: Post-harvest, will the seed survive and germinate within the confines of a managed field?

Whether seed enters the seed-bank because of seed spillage at sowing, pod shatter or harvesting, their ability to germinate and develop into volunteers affords them the potential to act as future sink populations.

CSV3: Will the volunteer develop into a viable individual?

By confining this strand to seeds that germinate within the boundary of a crop system, it is possible to differentiate between a crops ability to complete seed-mediated gene flow both inside and outside (see Sect. Strand CSF) the managed environment of the field.

\section{Strand CSF (Crop seed-to-feral gene flow)}

The tendency of a crop to establish a persistent population outside the boundaries of the field (via seed-mediated gene flow) is an important portal of gene flow for all crops and a significant issue when considered in the context of coexistence. Similar to Strand CSV, three questions can be employed to gauge the ability of an errant seed to develop into a feral individual:

CSF1: Does the crop produce seed during its cultivation?

CSF2: Following transfer from site of cultivation will wayward seed survive and germinate?

CSF3: Will the resulting individuals establish into a viable feral population?

The provision of CSF2 and CSF3 is informative for risk assessment purposes as they identify a crop's ecological viability, measured as an ability to compete for space and nutrients with the adjacent flora. Whereas certain crops (e.g. maize) will not establish a persistent population as they are unable to survive outside of cultivation (Gould, 1968). Certain crop species have the capacity to freely hybridize and backcross with wild and feral populations e.g. ryegrass and oilseed rape.

\section{MODEL IMPLEMENTATION}

Of the $64 \%$ (4.4 million $\mathrm{Ha}$ ) of the total land area (6.9 million Ha) used for agriculture in Ireland (Tab. 1), $80 \%$ is devoted to ryegrass (silage, hay and pasture) cultivation with $9 \%$ dedicated to crop production (Department of Agriculture and Food, 2004). This latter sector is primarily composed of barley, wheat, sugar beet, oilseed rape, potato and forage maize. These and ryegrass were included in the analysis not only because they are the priority crops in Irish agriculture but also because they represent a range of non/indigenous crops (Tab. 1). The proposed GFI value for each crop following passage through each of the four strands of the model is presented in Table 4, with supporting literature described below.

\section{Wheat}

Wheat has no wild relatives in Ireland so crop pollen-towild relative gene flow is of no concern: $\mathrm{CPW}=0$. Pollenmediated crop-to-crop gene flow will occur in wheat and within a commercial crop out-crossing rates in wheat can be high between neighboring plants (Hucl, 1996; Van Acker et al., 2003; Waines and Hegde, 2003) with up to $90 \%$ of pollen dispersed within $3 \mathrm{~m}$ of the pollen source; decreasing significantly up to $20 \mathrm{~m}$ (de Vries, 1974). Supported by other research findings (Brule-Babel et al., 2003; Loureiro et al., 2003), it can be concluded that $95 \%$ of wheat pollen is retained within $10 \mathrm{~m}$ of the crop border. Combined with wheat's ability to cross-pollinate (though it is primarily a self-fertilizer), it can be assumed that if fertilization is achieved, viable hybrids could establish themselves in the absence of appropriate management measures: implying $\mathrm{CPC}=5$. The emergence of volunteers in subsequent wheat crops is a regular occurrence in wheat cultivation (Beckie et al., 2001). Though management measures ensure that the majority of volunteers are removed, viable volunteers can be found in the rotation: $\mathrm{CSV}=3$. To date, feral wheat populations have not been reported in Ireland as current wheat varieties do not have the ability to establish themselves into a viable population outside the confines of cultivation: $\mathrm{CSF}=0$. 
Table 4. GFI assessment for wheat, barley, oilseed rape (OSR), maize, sugar beet (S. Beet), potato and ryegrass (grass), using the individual gene flow strands crop pollen-to-wild (CPW), crop pollen-to-crop (CPC), crop seed-to-volunteer (CSV) and crop seed-to-feral (CSF) as described in text and Table 3.

\begin{tabular}{|c|c|c|c|c|c|c|c|c|}
\hline \multirow{2}{*}{$\begin{array}{l}\text { CPW } \\
\text { Code }\end{array}$} & \multicolumn{8}{|c|}{ Propensity for successful pollen-mediated gene flow between the crop and wild relative } \\
\hline & Question & Wheat & Barley & OSR & Maize & S. beet & Potato & Grass \\
\hline CPW1 & Do interfertile wild relatives of this crop exist in Ireland? & 0 & 0 & 1 & 0 & 1 & 0 & 1 \\
\hline CPW2 & $\begin{array}{l}\text { Is there a probability that the crop will flower and produce viable } \\
\text { pollen during its cultivation? }\end{array}$ & --- & --- & 1 & --- & 1 & --- & 1 \\
\hline CPW3 & 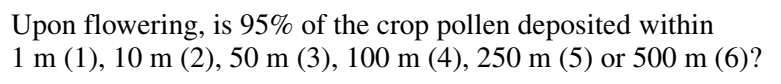 & --- & --- & 3 & --- & 6 & --- & 5 \\
\hline CPW4 & $\begin{array}{l}\text { If flowering does occur is the wild relative in question rated } \\
\text { as an obligate inbreeder ( } 0) \text {, a partial inbreeder/outbreeder (1) } \\
\text { or an obligate outbreeder (2)? }\end{array}$ & --- & --- & 1 & --- & 1 & --- & 2 \\
\hline CPW5 & $\begin{array}{l}\text { If fertilization is achieved by the deposited pollen, will a viable } \\
\mathrm{F}_{1} \text { hybrid individual establish itself? }\end{array}$ & --- & --- & 1 & --- & 1 & --- & 1 \\
\hline & Total & 0 & 0 & 7 & 0 & 10 & 0 & 10 \\
\hline CPC & \multicolumn{8}{|c|}{ Propensity for successful pollen-mediated gene flow between the crop and related commercial varieties } \\
\hline Code & Question & Wheat & Barley & OSR & Maize & S. beet & Potato & Grass \\
\hline $\mathrm{CPC} 1$ & $\begin{array}{l}\text { Is there a probability that the crop will flower and produce viable } \\
\text { pollen during its cultivation? }\end{array}$ & 1 & 1 & 1 & 1 & 1 & 1 & 1 \\
\hline $\mathrm{CPC} 2$ & $\begin{array}{l}\text { Upon flowering, is } 95 \% \text { of the crop pollen deposited within } \\
1 \mathrm{~m}(1), 10 \mathrm{~m} \mathrm{(2),50} \mathrm{m} \mathrm{(3),} 100 \mathrm{~m}(4), 250 \mathrm{~m} \text { (5) or } 500 \mathrm{~m}(6) ?\end{array}$ & 2 & 2 & 3 & 3 & 6 & 2 & 5 \\
\hline CPC3 & $\begin{array}{l}\text { If flowering does occur is the receptive crop rated as an obligate } \\
\text { inbreeder }(0) \text {, a partial inbreeder/outbreeder (1) or an obligate } \\
\text { outbreeder (2)? }\end{array}$ & 1 & 1 & 1 & 1 & 1 & 1 & 2 \\
\hline CPC4 & $\begin{array}{l}\text { If fertilization is achieved by the deposited pollen, will a viable } \\
\mathrm{F}_{1} \text { individual establish itself from the hybrid seed in the absence } \\
\text { of mechanical/chemical control? }\end{array}$ & 1 & 1 & 1 & 1 & 1 & 1 & 1 \\
\hline & Total & 5 & 5 & 6 & 6 & 9 & 5 & 9 \\
\hline
\end{tabular}

CSV Propensity for successful seed-mediated gene flow from crop to volunteer

\begin{tabular}{|c|c|c|c|c|c|c|c|c|}
\hline Code & Question & Wheat & Barley & OSR & Maize & S. beet & Potato & Grass \\
\hline CSV1 & Does the crop produce seed during its cultivation? & 1 & 1 & 1 & 1 & 1 & 1 & 1 \\
\hline CSV2 & $\begin{array}{l}\text { Post-harvest, will the seed survive and germinate within the } \\
\text { confines of a managed field? }\end{array}$ & 1 & 1 & 1 & 1 & 1 & 1 & 1 \\
\hline CSV3 & Will the volunteer develop into a viable individual? & 1 & 1 & 1 & 1 & 1 & 1 & 1 \\
\hline & Total & 3 & 3 & 3 & 3 & 3 & 3 & 3 \\
\hline
\end{tabular}

\begin{tabular}{|c|c|c|c|c|c|c|c|c|}
\hline CSF & Propensity for successful seed-mediated gene flow from comn & ercial cr & p to fera & & & & & \\
\hline Code & Question & Wheat & Barley & OSR & Maize & S. beet & Potato & Grass \\
\hline CSF 3 & Does the crop produce seed during its cultivation? & 1 & 1 & 1 & 1 & 1 & 1 & 1 \\
\hline CSF & $\begin{array}{l}\text { Following transfer from the site of cultivation will wayward seed } \\
\text { survive and germinate? }\end{array}$ & 1 & 1 & 1 & 1 & 1 & 1 & 1 \\
\hline CSF 3 & $\begin{array}{l}\text { Will the resulting individuals establish into a viable feral } \\
\text { population? }\end{array}$ & 0 & 0 & 1 & 0 & 1 & 1 & 1 \\
\hline & Total & 0 & 0 & 3 & 0 & 3 & 3 & 3 \\
\hline
\end{tabular}




\section{Barley}

Similar to wheat, barley has no wild relatives in Ireland so the issue of crop pollen-to-wild relative gene flow does not arise: $\mathrm{CPW}=0$. During its cultivation barley does flower and set seed. So while the crop primarily reproduces through self-fertilization (approx. 99\%; see Eastham and Sweet, 2002), a mechanism for crop pollen-to-crop gene flow does exist. Yet, the dispersal of barley pollen is limited and over $95 \%$ of out-crossing events will occur within $10 \mathrm{~m}$ of the source (Ritala et al., 2002). As hybridization will occur, individuals will emerge the following season if control measures are not adopted: $\mathrm{CPC}=5$. Comparable to wheat, seed-mediated crop-to-volunteer gene flow can occur, albeit at a very low frequency: $\mathrm{CSV}=3$. The potential for seed-mediated crop-to-feral gene flow has not been reported for barley in Irish tillage systems: $\mathrm{CSF}=0$.

\section{Oilseed rape}

Several inter-fertile wild relatives of oilseed rape exist in Ireland (Tab. 1) and flowering is required for seed set to occur. Consequently, pollen-mediated crop pollen-towild or crop pollen-to-crop gene flow depends not only on successful pollination of the related wild species/crop variety, but also on the viability of any resulting hybrids. Pollen-mediated gene flow in oilseed rape has been the focus of numerous studies (reviewed by Eastham and Sweet, 2002; Salisbury, 2002), from which it can be determined that $95 \%$ of oilseed rape pollen is deposited within $50 \mathrm{~m}$ of the pollen donor population. As the formation of crop-to-crop/wild hybrids is not atypical for oilseed rape cultivation (Salisbury, 2002) index values for strand CPW and CPC equate to 7 and 6 respectively. Following cultivation, the emergence of oilseed rape volunteers within a rotation is guaranteed. While the establishment of viable volunteers that continue to flower is effectively controlled when oilseed rape is introduced as a break crop within a cereal rotation. It must be acknowledged that volunteers can prove challenging to manage, especially when they occur in long-lived seed banks: $\mathrm{CSV}=3$. The emergence of oilseed rape feral populations outside the influence of cultivation practices is also a reality (Ramsay et al., 2003) and underlines the ability of the crop to adapt and compete in an uncontrolled environment: $\mathrm{CSF}=3$.

\section{Maize}

Maize has no wild relatives in Ireland so pollen-derived crop-to-wild relative gene flow cannot occur: $\mathrm{CPW}=0$.
The dispersal patterns of maize pollen have been reviewed (Eastham and Sweet, 2002) with an average of 95\% deposited within $50 \mathrm{~m}$ of the crop margin (Sears and Stanley-Horn, 2000). Though maize is solely cultivated in Ireland for forage use, the establishment of a viable crop pollen-to-crop hybrid is considered possible: $\mathrm{CPC}=6$. Though infrequent, viable maize volunteers can occur in the rotation, particularly in those areas that escape winter frosts: $\mathrm{CSV}=3$. Coupled with its non-invasiveness and excessive domestication, which has seen maize lose the ability to survive and maintain itself in the wild (USDA, 2002); cultivated maize is not considered a weed outside of agricultural fields: $\mathrm{CSF}=0$.

\section{Sugar beet}

Cultivated sugar beet co-exists with two inter-fertile wild relatives in Ireland: "sea beet" (Beta vulgaris spp. maritima) and "weed beet". Though flowering is disadvantageous for crop production the appearance of flowering bolters is commonly associated with beet cultivation in Ireland. Hybridization between bolting sugar beet and flowering weed/sea beet may therefore provide a mechanism for gene exchange (Bartsch et al., 2003; Boudry et al., 1993). Pollen diffusion from sugar beet can be extensive with outcrossing rates measured at $15 \%$ over 250 m (Van Raamsdonk and Schouten, 1997) and $6 \%$ over $800 \mathrm{~m}$ (Treu and Emberlin, 2000). This combined with the fact that hybrid seed can establish itself into viable populations, implies strand CPW and CPC register indices of 10 and 9 respectively. As vernalized root fragments and bolter seed can contribute to large populations of viable weed beet (Pohl-Orf et al., 2000), the control of volunteer populations can prove difficult for crop management systems: $\mathrm{CSV}=3$. Outside the boundaries of cultivation, sugar beet is similar to oilseed rape in that seed can germinate and establish into a viable feral under certain conditions (Teagasc Advisory Service, personal communication) $\mathrm{CSF}=3$.

\section{Potato}

Two wild relatives of potato exist in Ireland (Tab. 1). As neither species is fertile with present commercial varieties, potato is considered to be a naturally contained species within Europe (Eijlander and Stiekeman, 1994): $\mathrm{CPW}=0$. The dispersal of potato pollen is an issue in certain regions of Ireland where potato is cultivated for both tuber and true potato seed (TPS) production. Dispersal distances for potato pollen are typically less than 10 m (McPartlan and Dale, 1994; Tynan et al., 1990) and 
while most commercial varieties are sterile, hybridization can occur, hence a potential exists for the resulting TPS to establish into a viable population: $\mathrm{CPC}=5$. The appearance of potato volunteers emerging from overwintered groundkeepers is a serious problem for potato growers and hence a feasible mechanism for seedmediated gene flow: $\mathrm{CSV}=3$. Similarly, groundkeepers can develop into viable ferals if they evade typical control measures applied within the confines of cultivation: $\mathrm{CSF}=3$.

\section{Ryegrass}

Ryegrass is a native species of Ireland (Tab. 1) and is widely cultivated both as a forage crop and for the purposes of seed multiplication. Though flowering is undesirable on an agricultural scale, it frequently occurs and results in reduced quality of the forage. Ryegrass pollen can travel considerable distances with outcrossing rates of 5\% (Levin and Kerster, 1974) to $17 \%$ (Van Raamsdonk and Schouten, 1997) recorded at distances ranging from $300 \mathrm{~m}$ to $250 \mathrm{~m}$ respectively for varying ryegrass species. An obligate outbreeder, pollen-mediated crop-to-crop and crop-to-wild hybridization in ryegrass has been confirmed in Ireland and will result in the production of viable hybrids (Eimear Ryan, personal communication): implying GFI values for CPW and CPC of 10 and 9 respectively. As with the previous crops, crop seed-to-volunteer gene flow in a crop-rotation situation is likely to occur: $\mathrm{CSV}=3$. For L. perenne (the predominant Lolium species cultivated in Ireland) seeds that arise during cultivation can develop into viable ferals (Eimear Ryan, personal communication): $\mathrm{CSF}=3$.

\section{MODEL DISCUSSION}

Our report expands upon the concept of gene flow indices by addressing within a single index, the four primary modes of gene dispersal from a crop. Specifically, these include pollen-mediated crop-to-wild relative (CPW) and crop-to-crop (CPC) gene flow and seed-mediated crop-tovolunteer (CSV) and crop-to-feral (CSF) gene flow (Fig. 1A). For all four strands the decisive factor for successful gene flow is deemed to be the establishment of a viable, reproducing hybrid/volunteer/feral individual, without which the introgression/gene spread exposure element of any GM crop risk assessment could not occur. By restricting the analysis to just the dispersal and preliminary stage of establishing a viable individual/ population, it is accepted that the model excludes the issue of hybrid/feral competitive ability. It does however provide an initial data set that will quantify the propensity of a conventional crop to spread its genetic material, which could help in the formulation of sustainable coexistence management plans.

Crop pollen-to-wild gene flow (CPW) is deemed effective upon the completion of five successive steps that precipitate the establishment of a viable crop-wild hybrid (Tab. 3). Although significant data exists on pollen dispersal for the listed crops the extrapolation of certain data sets to reflect Irish agro-ecological conditions posed a significant problem during the course of this research. Coupled with the recommendation that experimental work should be completed on a regional scale (Ammann et al., 2001), these knowledge gaps serve to highlight the need for specific gene-flow studies in Ireland.

Of more significance to coexistence is the likelihood of crop pollen-to-crop gene flow (CPC). In this study, a crop's potential for pollen-mediated gene flow to a related crop is calculated over four sequential questions beginning with a question on the presence/absence of flowers during the crop's cultivation (Tab. 3, CPC1). The consequence of pollen dispersal distances and the ability of the receptor plant to receive donated pollen are also addressed (CPC2 and CPC3). In a professional farm system, few scenarios exist where management measures would not be implemented to control unwanted hybrids. Letting the land go fallow is one circumstance however, as is the situation where a farmer saves seed for future cultivation. A common practise within the organic sector, farm saved seed provides a situation that could challenge the labelling regimes of coexistence through pollen-mediated admixture. An example of how this might arise could centre on the adventitious presence of GM-derived pollen (e.g. expressing herbicide tolerance) within an organic crop, which has been cultivated for farm saved seed purposes. Assuming hybridization has occurred, the subsequent cultivation of the farm saved seed could include viable hybrid seed containing the herbicide tolerant trait. The persistence of such CPC-derived $\mathrm{F}_{1}$ hybrids within the confines of cultivation (either in the source field or elsewhere) will be clearly dependent upon the presence/absence of mechanical/chemical control and will have obvious consequences for crop management, labelling and the organic status of the grower.

Primarily managed through appropriate rotation and chemical control, volunteers become a significant issue when management practices prove inadequate and volunteers are left flower or tuberize. In this model, the potential for crop seed-to-volunteer gene flow is demonstrated across all seven crops through strand CSV. Though associated with all the listed crops, volunteer 


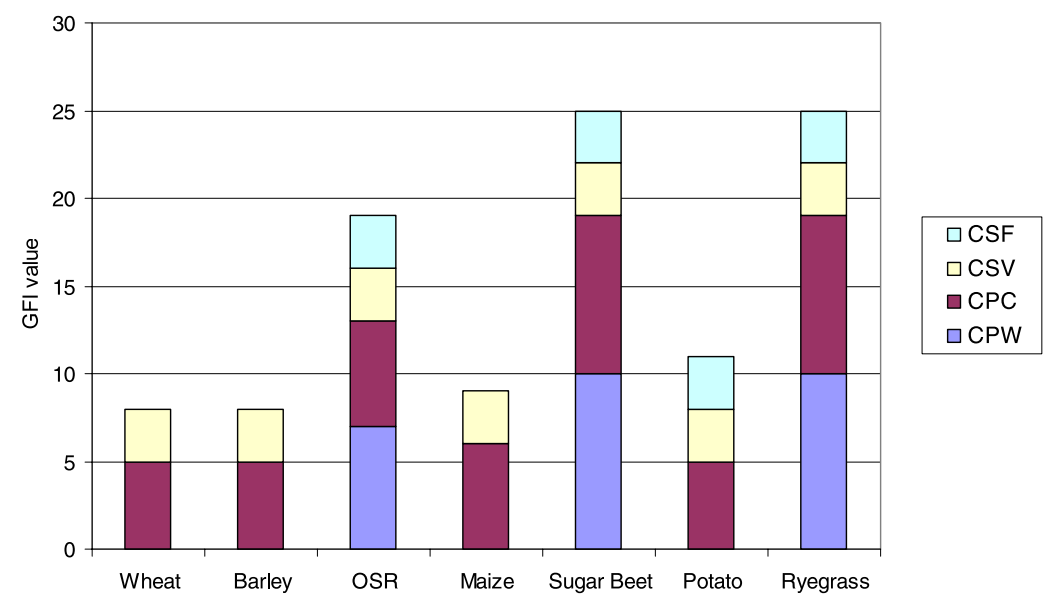

Figure 2. Graphical representation of combined pollen and seed-mediated gene flow for wheat, barley, oilseed rape (OSR), maize, sugar beet, potato and ryegrass. GFI values attained from strands CSF, CSV, CPC and CPW (see Tab. 4). emergence is clearly a greater problem for a select number of crops: for example oilseed rape, sugar beet, potato, ryegrass and to a lesser extent wheat. While desirable, it was not possible in this study to quantify this distinction between the crops due to a scarcity of Irish-specific agronomic data. The potential of volunteers to establish themselves within a rotation and ultimately act as a "genetic bridge" for the transfer of transgenes is a critical issue for coexistence. While the worst-case scenario approach adopted in this analysis (Tab. 3) underlines the potential of each crop to give rise to volunteers: it is evident that further research is required in order to determine the potential of crop volunteers to persist and facilitate gene transfer into related wild/cultivated species.

For those individuals that are located outside the zone of cultivation, strand CSF describes the expected outcome of that seed which has been un/intentionally transferred from the site of cultivation. This includes wayward seed that has fallen into the field hedgerow or has been dispersed along the roadside following transport to the first point of sale. In such an environment fallen seed is outside the influence of the farm system and though an advantage, the unmanaged environment of the hedgerow introduces a novel pressure on the seed: will the emerging individual establish into a viable feral population? For the majority of crops currently cultivated in Ireland this is not a likely development both because of the level of domestication they have undergone in order to maximize their agronomical potential and because the Irish agroecological environment differs markedly from the ecosystems where these crops were first domesticated. For other crops, notably ryegrass and oilseed rape, the life history and niche strategy of the cultivated varieties is better suited to ambient Irish environmental conditions and this is reflected in the positive CSF scores for both these species (Tab. 4).

A composite GFI value for each crop was calculated by combining the attained values from each of the four strands (Tab. 4). Represented schematically (Fig. 2), the high propensity of both conventional ryegrass and sugar beet to disperse their genetic material is clear, with each attaining a GFI value of 25 out of a maximum 27 (Fig. 2). The justification for such a value is supported by the fact that both species co-exist in Ireland with inter-fertile wild relatives, both can disperse their pollen over large distances and the initiation of feral populations from each species is a reality. Importantly, the high GFI value for conventional sugar beet does not necessarily advocate the non-cultivation of GM sugar beet in Ireland. Conversely, it underlines the importance of bolter control in the effective coexistence of GM and non-GM sugar beet. This point is emphasized by re-submitting the sugar beet data into a coexistence-themed model that assumes stringent bolter control is achieved during cultivation. In this scenario the model produces a GFI score of 6 , where the potential for gene flow is minimized to the establishment of volunteer and feral populations from harvested tuber fragments. Further modifications could be applied to the model by estimating the potential for gene flow at a local level as opposed to the national scale presented here (Tab. 4 and Fig. 2). For example, as B. vulgaris ssp. maritima is typically localized along the coastal regions and if bolter control was not practiced/achievable, the consolidation of sugar beet cultivation to the inland regions would further reduce the total GFI value for the crop by negating the potential for crop pollen-to-wild gene flow.

A GFI value of 19 for oilseed rape (Fig. 2) confirms the ability of this species to disperse its genetic material 


\section{M.-L. Flannery et al.}

(Eastham and Sweet, 2002). In contrast to sugar beet $(\mathrm{GFI}=25)$, flowering is required in oilseed rape. Hence, potential mechanisms to reduce the GFI value for oilseed rape from the perspective of coexistence are limited to the implementation of large isolation distances (Tolstrup et al., 2003) and measures to reduce post-harvest seed loss.

The potential for pollen and seed-mediated gene flow in potato $(\mathrm{GFI}=11)$ relates to combined tuber and true potato seed (TPS) production. If the model is applied to those counties in Ireland where cultivation relates solely to tuber production, the present GFI value is reduced from 11 to 6 . The combined value $(\mathrm{GFI}=11)$ is weighted due to the potential for crop pollen-to-crop gene flow arising from TPS production and demonstrates the "worst-case scenario" approach that has been adopted for the model. Consequently, this GFI value could be considered high for a crop that is largely grown for tuber production, from which potential modes of gene flow would only arise through volunteer (CSV) and feral (CSF) establishment; hence the alternative value, $\mathrm{GFI}=6$.

Both wheat and barley recorded a low potential for gene flow (Tab. 4 and Fig. 2) because of the zero scores returned through strands CPW and CSF. Such a natural restriction highlights the reduced potential of gene flow that would be associated with the commercialization of GM wheat/GM barley in Ireland. In light of recent research (Van Acker et al., 2003), volunteer management would still be an essential requirement for efficient coexistence and though cereal seed multiplication is lowscale in Ireland, in those areas where it is carried out, additional precautions may be required.

The absence of inter-fertile relatives, coupled with the domestication of maize, limits potential pollen-mediated crop-to-wild gene flow and the establishment of viable ferals from the forage maize crop presently cultivated in Ireland. The propensity for gene flow arising from maize is limited to pollen-mediated crop-to-crop and seedmediated crop-to-volunteer. Though the likelihood of both/either event occurring is minimal, the manner in which the model has been designed accentuates the fact that either event can occur; hence CSV $=3$ and $\mathrm{CPC}=6$.

In addition to the four strands of gene flow discussed in this model, it is important to acknowledge secondary gene flow scenarios, which though traceable back to the four strands identified in this model, could cause difficulties for pending coexistence strategies. Of particular concern would be the potential outcomes of gene flow from wild relative populations, which were original recipients under CPW and CSF (Fig. 1A). Pollen and seed mediated gene flow events can occur from WR populations back into the primary field source $\left(1^{\circ}\right)$ and into secondary fields $\left(2^{\circ}\right)$ not associated with the original cultivation, providing the hybrid progeny are viable (Fig. 1B). As wild/weedy populations are rarely subject to or amenable to control measures, these gene flow events can continue for many generations. For coexistence, this underlines the importance of a post-release monitoring strategy, which surveys those non-cultivated niches that have been populated with wild relatives of adjacent crops.

The potential outcomes of gene flow under strands CPC and CSV (Fig. 1C) are also significant to coexistence; where following the emergence of viable CPC and/ or CSV-derived individuals within the crop of a secondary field $\left(2^{\circ}\right)$ the farm manager may be unaware of any adventitious presence within this crop (Fig. 1C). If the purpose of this crop is for conventional seed multiplication (SM) and/or farm saved seed (FSS), this will serve to facilitate vertical gene flow in follow-on cultivations. As there would be no requirement for pollen/seed management originating from such a field compared to a known GM crop, this will provide a reciprocal gene flow route back into other fields (GM or non-GM) and related wild populations. The consequence of this is largely unknown. Firstly it is dependent upon farmers not adhering to coexistence measures and on the failure of post-release monitoring to detect the problem. If however, both these criteria were to occur, it can be envisioned that in the long-term (after several years of intense GM cultivation) it would become increasingly difficult for the original coexistence guidelines to achieve the requisite thresholds of admixture as laid down for labelling and marketing purposes.

\section{CONCLUSION}

The principal objective of this research was to establish a baseline gene flow data set (that includes four primary modes of gene flow) for Ireland's primary crops through the provision of a simple numerical index. Following on from this, it is intended that the model will complement the assessment of future GM crops due to the availability of a set of reference GFI values against which the potential for gene flow of a particular GM variety/trait could be compared. This is a novel approach that has not been described to date and though the coexistence of GM, conventional and organic crops on Irish farms in the future cannot be ruled out. By investigating the propensity of a crop for gene flow, we foresee that this model could serve as a predictive tool to assist in pre-release risk assessment and post-release monitoring strategies.

Clearly, it is imperative that a distinction be made between the potential for gene flow and the consequence 
of gene flow. Ecologically, the consequence of gene flow is wholly dependent upon the physiological impact of the transgene and must be addressed on a case-by-case basis. In contrast, the potential for gene flow is primarily reliant upon the reproductive biology of the crop and this can be addressed by calculating a crop's GFI value. In this research, several crops (oilseed rape, ryegrass and sugar beet) attained a high GFI value. It must not be implied for this result that these crops are not suitable for GM development. Similarly, for the crops that scored low GFI values, this does not imply gene flow will not occur. Rather a high GFI score implies that a specific crop/variety possesses a higher propensity for gene flow and thus requires greater management precautions if successful coexistence is to be attained. Conversely, a low GFI value indicates a crop which should not pose a significant challenge to the implementation of a coexistence strategy. This is evident in the case of sugar beet where a crop system which controls bolters has the capacity to reduce the GFI value from 25 to 6 . What is clear from this work and reported previously (Sweet et al., 2004), is that if GM crops are to be cultivated in Ireland, crop management systems must be variety specific and take into account the cultivation of related, adjacent non-GM crops. This latter point specifically relates to the practice of seed multiplication, which from an Irish context is relevant to potato, ryegrass and to a lesser extent wheat and barley.

Logistically, the effectiveness of any coexistence strategy for Ireland will be dependent upon (1) the implementation of appropriate isolation distances to minimize the impact of pollen transfer (2) sound land management to ensure adequate volunteer and feral control (3) the efficient hygiene of farm machinery and (4) the effective segregation of seed at all stages pre- and postcultivation. The described model engages two issues that are central to successful coexistence: pollen transfer and seed dispersal. A crop's propensity to secure successful field-to-field gene flow through either pollen transfer or seed dispersal is addressed through strand CPC and CSV respectively. Though ancillary, the management of ferals and wild relatives adjacent to the site of cultivation will prove an important coexistence associated task. Hence, a crop's potential for pollen-mediated gene flow to wild relatives (CPW) and/or the establishment of ferals (CSF) is also examined.

Though coexistence is not a novel concept in the Irish tillage industry (e.g. successful segregation of crops for seed certification purposes by the Department of Agriculture and Food), its achievement in regard to GM crops is critical. Post-implementation, the efficacy of any coexistence regime must be monitored through an interdisciplinary program of research that runs in parallel with any GM crop cultivation in Ireland. Notably, our work has highlighted several coexistence-based questions that require further research and which should be addressed prior to the commercialization of GM crops in Ireland. Specifically, the potential for seed-mediated gene flow requires significant focus. This became evident during the formulation of the CSV and CSF strands, where due to a scarcity of research data, we were limited in the number of questions we could ask in regard to the efficacy of seed-mediated gene flow for each crop. This contrasts with pollen-mediated gene flow (strand CPW and CPC), for which there was a substantial research data set available. The role of volunteers is of particular concern because it would be naïve to assume that total volunteer control will be achieved in a coexistence-based management system. Therefore, several questions need to be addressed. For example; in those cases where there is a degree of irresponsibility in regards to machine hygiene, what are the ecological implications of such noncompliance? Would a persistent GM containing volunteer population within/adjacent to a conventional field result in sufficient admixture to exceed the thresholds? If so how long will it take in the rotation and what size must the volunteer population be? Would such a population act as a "genetic bridge" to facilitate vertical gene flow to adjacent fields/niches (Fig. 1C)? These are important questions that will increase our understanding of the issues and assist in the modification of a coexistence regime which must by dynamic in order to respond to both agricultural and ecological challenges.

For Ireland, and other countries that have/will legislate for coexistence, the outcome of excessive gene flow from a GM crop into a related conventional crop will present economic issues for the industry. However, the potential admixture of conventional and GM crop derived material that has been developed for non-food use could present both economic and social consequences. Specifically, this relates to the use of traditional crops for non-food use; for example the production of therapeutics (Thanavala et al., 2005) and biodegradable plastics (Romano et al., 2005). For Ireland, the cultivation of these second and third generation GM crops could provide the tillage industry with the level of diversification it seeks in order to address current market pressures. However, such non-food GM crops should only be introduced into an industry that has developed a proven system of GM/non-GM coexistence. To establish such a system, the suitability of each GM crop must first be assessed by determining the equivalent nonGM crop's potential for gene flow. Once this has been achieved, the impact of the particular GM trait on the crops 


\section{M.-L. Flannery et al.}

potential for gene flow can then be incorporated into the associated risk assessment to determine the consequences of said gene flow.

From a non-scientific perspective, it is hoped that the GFI ranking scheme will increase the public's understanding of "gene flow", an issue central to the GM debate. Within the scientific community, it is hoped that the described index will revive discussion on the merits of gene flow indices; specifically in regard to the feasibility of establishing a collective GM crop risk index that encompasses not only a crop's propensity for gene flow but also the elements that contribute to invasiveness, changes in genetic diversity and broader ecological disturbance (Conner et al., 2003; Hancock, 2003; Meade and Mullins, 2005; Newstrom et al., 2003).

Received November 16, 2004; accepted June 21, 2005.

\section{REFERENCES}

Advisory Committee on Releases to the Environment (2004) Advice on scientific issues concerning the proposed regime for the co-existence of GM and non-GM crops. p 6. http:// www.defra.gov.uk/environment/acre/advice/pdf/acre_advice56.pdf

Ammann K, Jacot Y, Al Mazyad RP (2001) Safety of genetically engineered plants: an ecological risk assessment of vertical gene flow. In Custers R, ed, Safety of Genetically Engineered Crops. Zwijnaarde, Belgium, Flanders Interuniversity, Institute for Biotechnology, pp 60-87

Bartsch D, Brand U, Morak C, Pohl-Orf M, Schuphan I, Ellstrand NC (2001) Biosafety of hybrids between transgenic virus-resistant sugar beet and Swiss chard. Ecol. Appl. 11: 142-147

Bartsch D, Cuguen J, Biancardi E, Sweet J (2003) Environmental implications of gene flow from sugar beet to wild beet - current status and future research needs. Environ. Biosafety Res. 2: 105-115

Beckie HJ, Hall LM, Warwick SI (2001) Impact of herbicideresistant crops as weeds in Canada. Proceedings of British Crop Protection Conference: Weeds, pp 135-142

Boudry P, Mörchen M, Saumitou-Laprade P, Vernet P, Van Dijk H (1993) The origin and evolution of weed beets: consequences for the breeding and release of herbicide resistant transgenic sugar beets. Theor. Appl. Genet. 87: 471478

Brule-Babel AL, Van Acker RC, Friesen LF (2003) Issues related to release of GM wheat: gene flow and selection. Proceedings of the 2002 Manitoba Agronomists Conference, University of Manitoba, Winnipeg, Canada

Conner AJ, Glare TR, Nap JP (2003) The release of genetically modified crops into the environment. Part II. Overview of ecological risk assessment. Plant J. 33: 19-46 de Vries AP (1974) Some aspects of cross pollination in wheat (Triticum aestivum L.). Seed set on male sterile plants as influenced by distance from the pollen source. Pollinator: Male sterile ratio and width of the male sterile strip. Euphytica 23: 601-622

de Vries AP, Meijden VD, Brandenburg WA (1992) Botanical files - a study of the real chances for spontaneous gene flow from cultivated plants to the wild flora of the Netherlands. Gorteria, Supplement 1, p 100

DEFRA (2001) Risk assessment for release and marketing of GMOs in the European Union. http://www.defra.gov.uk/ environment/gm/background/risk

Department of Agriculture and Food (2004) Fact sheet on Irish agriculture: May 2004, p 2

Devos Y, Reheul D, de Schrijver A, Cors F, Moens W (2004) Management of herbicide-tolerant oilseed rape in Europe: a case study on minimizing vertical gene flow. Environ. Biosafety Res. 3: 135-148

Eastham K, Sweet J (2002) Genetically modified organisms (GMOs): The significance of gene flow through pollen transfer. Environmental Issue Report No. 28, p 75

Eijlander R, Stiekeman WJ (1994) Biological containment of potato (Solanum tuberosum): Outcrossing to the related wild species black nightshade ( $S$. nigrum) and bittersweet $(S$. dulcamara). Sex. Plant R. 7: 29-40

European Commission (2003) Guidelines for the development of national strategies and best practices to ensure the co-existence of genetically modified crops with conventional and organic farming, Commission Recommendation 2003/556/EC. http://europa.eu.int/comm/agriculture/publi/reports/ coexistence $2 /$ index_en.htm

Frietema De Vries FT (1996) Cultivated plants and the wild flora. Effect analysis by dispersal codes. Rijksherbarium, Leiden

Gould FW (1968) Grass Systematics. New York, McGraw Hill, p 382

Hancock JF (2003) A framework for assessing the risk of transgenic crops. BioSci. 53: 512-519

Hauser TP, Bjorn GK, Magnussen L, Shim SI (2003a) Hybrids between cultivated and wild carrots: a life history. European Science Foundation, Assessment of the Impacts of Genetically Modified Organisms: Introgression from genetically modified plants to wild relatives and its consequences, University of Amsterdam, Amsterdam, January 21-24

Hauser TP, Damgaard C, Jorgensen RB (2003b) Frequencydependent fitness of hybrids between oilseed rape (Brassica napus) and weedy B. rapa (Brassicaceae). Amer. J. Bot. 90: 571-578

Hucl P (1996) Out-crossing rates for 10 Canadian spring wheat cultivars. Can. J. Plant Sci. 76: 423-427

Levin DA, Kerster HW (1974) Gene flow in seed plants. Evol. Biol. 7: 139-200

Loureiro I, Escorial MC, Garcia-Baudin JM, Chueca MC (2003) Pollen dispersal and potential hybridisation between wheat cultivars. In Boelt B, ed, 1st European Conference on 
Co-existence of Genetically Modified Crops with Conventional and Organic Crops, Research Centre Flakkebjerg, pp 85-88

McPartlan H, Dale PJ (1994) The transfer of introduced genes from field grown transgenic potatoes to non-transgenic potatoes and related Solanaceous species. Transgenic Res. 3 : 216-225

Meade C, Mullins E (2005) GM crop cultivation in Ireland: Ecological and Economic considerations. Proc. R. Ir. Acad.: Biol. Environ. 105B: 33-52

Newstrom LE, Armstrong T, Robertson AW, Lee WG, Heenan PB, Peltzer D, Wilton AD, FitzJohn RG, Breitwieser I, Glenny D (2003) Environmental Risks to the New Zealand Flora from Transgenic Crops: the role of gene flow. Landcare Research, Lincoln, p 76. www.landcareresearch.co.nz/research/biodiversity/geneflow

Pohl-Orf M, Morak C, Wehres U, Saeglitz C, Drießen S, Lehnen M, Hesse P, Mücher T, von Soosten C, Schuphan I, Bartsch D (2000) The environmental impact of gene flow from sugar beet to wild beet: An ecological comparison of transgenic and natural virus tolerance genes. In Fairbairn $\mathrm{C}$, Scoles G, McHughen A, eds, Proceedings of the 6th International Symposium on The Biosafety of Genetically Modified Organisms, July 2000, Saskatoon, Canada, pp 51-55

Preston CD, Pearman DA, Dines TD (2002) New Atlas of the British and Irish Flora. Oxford, Oxford University Press

Programme UNE (2003) The UNEP-GEF project on the implementation of the national biosafety framework of Bulgaria. United Nations Environmental Programme, Division of Global Environment Facility Coordination. http://www.unep.ch/ biosafety/Implementation/countries/Bulgariaoperationalreport\%202003_12final.pdf

Ramsay G, Thompson C, Squire G (2003) Quantifying landscape-scale gene flow in oilseed rape. Scottish Crop Research Institute, Invergowrie, Dundee and DEFRA, Project RG0216. http://www.defra.gov.uk/environment/gm/research/pdf/epg rg0216.pdf

Raybould AF, Gray AJ (1993) Genetically modified crops and hybridisation with wild relatives: A UK perspective. J. Appl. Ecol. 30: 199-219

Ritala A, Nuutila AM, Aikasalo R, Kauppinen V, Tammisola J (2002) Measuring gene flow in the cultivation of transgenic barley. Crop Sci. 42: 278-285

Romano A, Plas LHW, Witholt B, Eggink G, Mooibroek H (2005) Expression of poly-3-(R)-hydroxyalkanoate (PHA) polymerase and acyl-CoA-transacylase in plastids of transgenic potato leads to the synthesis of a hydrophobic polymer, presumably medium-chain-length PHAs. Planta 220: $455-464$

Salisbury P (2002) Pollen movement in canola (Brassica napus) and outcrossing between B. napus crops. Environmental Safety Report, University of Melbourne, p 22
Sears MK, Stanley-Horn DE (2000) Impact of $B t$ corn pollen on monarch butterfly populations. In Fairbairn C, Scoles G, McHughen A, eds, Proceedings of the 6th International Symposium on The Biosafety of Genetically Modified Organisms, July 2000, Saskatoon, Canada

Stace CA (1984) Hybridization and the flora of the British Isles. Botanical Society of the British Isles, Academic Press, London, p 626

Sweet J, Simpson E, Law JR, Lutman P, Berry K, Payne R, Champion G, May M, Walker K, Wightman P, Lainsbury M (2004) Botanical and rotational implications of genetically modified herbicide tolerance in winter oilseed rape and sugar beet (BRIGHT Project). HGCA Project Report: p 265

Thanavala Y, Mahoney M, Pal S, Scott A, Richter L, Natarajan N, Goodwin P, Arntzen CJ, Mason HS (2005) Immunogenicity in humans of an edible vaccine for hepatitis B. Proc. Natl. Acad. Sci. U.S.A. 102: 3378-3382

Tolstrup K, Andersen SB, Boelt B, Buus M, Gylling M, Holm PB, Kjellsson G, Pedersen S, Ostergard H, Mikkelsen SA (2003) Report from the Danish Working Group on the Co-existence of genetically modified crops with conventional and organic crops. DIAS Report Plant Production No. 94, p 275

Treu R, Emberlin J (2000) Pollen dispersal in the crops Maize (Zea mays), Oil seed rape (Brassica napus ssp oleifera), Potatoes (Solanum tuberosum), Sugar beet (Beta vulgaris ssp. vulgaris) and Wheat (Triticum aestivum). A report for the Soil Association, National Pollen Research Unit, University College Worcester, p 54

Tynan JL, Williams MK, Conner AJC (1990) Low frequency of pollen dispersal from a field trial of transgenic potatoes. $J$. Genet. Breed. 44: 303-306

USDA (2002) Fact Sheet: Environmental Considerations for Bio-Engineered Crops in U.S. Food Aid Donations, Bureau of Economic and Business Affairs, Washington DC. http:// www.state.gov/e/eb/rls/fs/15605.htm

Van Acker RC, Brûlé-Babel AL, Friesen LF, Entz MH (2003) GM/non-GM wheat co-existence in Canada: Roundup Ready ${ }^{\circledR}$ wheat as a case study. In Boelt B, ed, 1st European Conference on Co-existence of Genetically Modified Crops with Conventional and Organic Crops, Research Centre Flakkebjerg, pp 60-71

Van Raamsdonk LWD, Schouten HJ (1997) Gene flow and establishment of transgenes in natural plant populations. Acta Bot. Neerl. 46: 69-84

Waines JG, Hegde SG (2003) Intraspecific gene flow in bread wheat as affected by reproductive biology and pollination ecology of wheat flowers. Crop Sci. 43: 451-463

Webb DA, Parnell JAN, Doogue D, Dundalk (1996) An Irish Flora. Dundalk, Dún Dealgan Press

Wilkinson MJ, Sweet J, Poppy GM (2003) Risk assessment of GM plants: avoiding gridlock? Trends Plant Sci. 8: 208-212 